\title{
ЦВЕТОВОДСТВО В РОССИИ: НЕ УПУСТИТЬ ШАНС Л.С. Шашкова
}

\author{
Редакция журнала «Цветоводство», Москва, Россия \\ Эл.noчma: lubashashkova47@yandex.ru \\ Статья проступила в редакцию 12.09.2016; принята к печати 12.10.2016
}

Дан обзор состояния цветоводства в России. Рассмотрены его различные аспекты: наука о цветах, производство срезочной продукции и посадочного материала, селекция декоративных культур, современные тенденции в этих областях. Обсуждается необходиость тесной связи научных изысканий с производством цветочных культур, практикой озеленения городов и других населенных пунктов. В числе перспективных научных направлений рассматривается проблема интродукции дикорастущих видов с красивыми цветками и декоративной листвой, дальнейшего их введения в культуру, включения этих видов в селекционные программы. В статье приводится печальная информация о сокращении любительской селекции, которая активно и успешно развивалась в стране начиная с 30-х гг. прошлого века, и поднимается вопрос об объединении усилий профессионалов и любителей в области создания новых перспективных сортов декоративных культур. Главная сегодняшняя проблема цветоводства в России - отсутствие общей программы его развития и координации действий между различными заинтересованными участниками. Отрадным явлением можно считать бурное развитие питомниководства в России в последние годы. Питомниководы сумели объединиться на взаимовыгодных условиях: они обмениваются опытом, посещая лучшие питомники России и мира, проводят научные конференции, участвуют в выставках, тесно сотрудничают с крупнейшими ландшафтными фирмами страны. Есть надежда, что это даст толчок новому этапу развития декоративного садоводства в стране. Совместные проекты ботанических садов и питомников (в числе последних уже есть несколько работающих с новыми современными биотехнологиями) могут способствовать возрождению селекции декоративных растений, введению в культуру новых высокодекоративных видов природной флоры, которыми так богата наша страна, развитию сотрудничества с зарубежными фирмами и питомниками, выходу отечественного цветоводства на мировой рынок.

Ключевые слова: ияветоводство, питомниководство, озеленение городов, селекция.

\section{FLORICULTURE IN RUSSIA: CHANCES MUST NOT TO BE MISSED L.S. Shashkova \\ Editorial Office, Tsvetovodstvo Magazin, Moscow, Russia E-mail: lubashashkova47@yandex.ru}

The current state of floriculture arts in Russia is reviewed. Current trends in the science of floriculture, florist's trade, and decorative flower breeding are considered. The expediency of their close collaboration with flower industry and landscaping is substantiated. Among the most promising trends are the introduction of wild-growing plant species having attractive flowers. However, amateurish selection of flowers, which used to be quite productive in this country as long as since nineteen thirties, is in decline now. Therefore, efforts by both amateurs and professional must be combined to rectify the current situation. The main problem of floriculture in Russia is currently the lack of coordination between all those concerned. An encouraging news is the explosive development of nursery gardens in Russia based on collaboration between gardeners who share their experience, visit the best nursery gardens in Russia and abroad, run conferences, organize exhibitions, and collaborate with landscapers. Hopefully, this can give impetus to decorative plant gardening using modern biotechnological approaches thus revitalizing decorative plant selection based on findings in the wild flora, which so rich in Russia. By collaboration with foreign florists and gardeners, this can help Russia in entering the global flower market.

Keywords: floriculture, nursery gardens, landscaping, selection.

\section{Вступление}

Не хочется повторять банальности, но, говоря о цветоводстве, нельзя не напомнить, что цветы, действительно, сопровождают нас в течение всей жизни - от рождения до смерти. Да и как жить без цветов? В городе - на клумбах, в квартирах - на окнах и в вазах, они радуют нас, повышают настроение, добавляют ярких красок в порой унылый пейзаж и в серую, подчас, жизнь. Не стоит забывать и о букетах, которые мы покупаем, когда идем в гости к родным и друзьям, на концерт любимого артиста, на свадьбу или, увы, на похороны. Для многих выращивание цветов становится прекрасным увлечением: кто-то разводит их на даче, удивляя соседей прекрасными розами, пионами, тюльпанами или более редкими культурами; кто-то - на окнах и стеллажах собирает коллекции кактусов, орхидей, узамбарских фиалок или стрептокарпусов; а кто-то идет еще дальше и пытается (часто довольно успешно) вывести новые сорта гладиолусов, георгин, хризантем или комнатных растений.

Что же такое «цветоводство» - серьезная наука или отрасль сельского хозяйства? Вот что говорит нам по этому поводу «Википедия»: цветоводство-отрасль растениеводства, занимающаяся селекцией и выращиванием красивоцветущих и других растений в декоративных целях: для срезки букетов, создания оранжерей и зеленых насаждений открытого грунта, а также для украшения жилых и производственных помещений.

Примерно такое же определение давала и Большая Советская энциклопедия. Но мне кажется, что это слишком поверхностное определение. Бесспорно, цветоводство - это отрасль растениеводства, а растениеводством - выращиванием различных культур - традиционно занимается сельское хозяйство, но цветы по каким-то причинам не попали в сферу интересов Министерства сельского хозяйства РФ. 
Академия коммунального хозяйства им. Памфилова, в которой в советское время над проблемами цветоводства и озеленения активно работали крупные ученые, сегодня «цветочных» тем не касается. В общем, на федеральном уровне цветоводство как отрасль осталось бесхозным.

Оставшиеся неприватизированными цветочные хозяйства сегодня находятся в городском ведении (так называемые ГУП, ГБУ и др.), а частные фирмы работают сами по себе.

В связи с вышесказанным трудно говорить о цветоводстве в масштабах страны, но попробуем это сделать на ряде примеров, в том числе Москвы.

Прежде всего, надо назвать «три источника и три составные части» цветоводства - науку о цветах, собственно выращивание цветочных и других декоративных культур (на срезку, для цветочного оформления населенных пунктов, для озеленения интерьеров), использование произведенного материала в озеленении. Есть еще одно важное направление использования цветов - флористика, но мастера этого искусства работают главным образом с импортной срезкой, поэтому в данной статье мы не будем об этом говорить.

\section{Наука - полководец?}

Так называл науку великий Леонардо да Винчи. Но сегодня, к сожалению, она не является приоритетом в нашей стране, государство не уделяет даже основополагающим наукам достаточного внимания и финансирования, а что уж говорить о цветоводстве, которое всегда считалось прикладной наукой. Тем не менее, ни одна отрасль промышленности или сельского хозяйства не может развиваться и двигаться вперед, не опираясь на достижения науки. Где же, в каких учреждениях занимаются вопросами цветоводства? Прежде всего, это ботанические сады. Некоторые из них относятся к системе РАН, другие являются подразделениями университетов или научных институтов. Есть и «титульное» учреждение - ФБГНУ ВНИИ цветоводства и субтропических культур в Сочи. Но, к сожалению, наука сегодня не в почете, бюджетное финансирование и ботанических садов, и Сочинского института далеко не достаточное, поэтому ждать от них каких-то сверхдостижений не приходится. Однако даже в таких, совсем не оптимальных условиях ученые работают, причем многие исследования напрямую связаны с цветоводством и озеленением.

Чтобы не быть голословной, приведу несколько примеров. В Главном ботаническом саду РАН активно проводятся работы по интродукции декоративных травянистых растений открытого грунта, которые в дальнейшем рекомендуются для использования в городском озеленении. Вопрос широкого применения многолетников на московских объектах чрезвычайно актуален, но сегодня их ассортимент не слишком велик - лилейники, хосты, астильбы, очитки и некоторые другие. На городских клумбах очень мало растений, цветущих осенью, хотя эта пора в средней полосе России длится долго, и очень желательно, чтобы цветники в пасмурную дождливую пору долго радовали горожан яркими красками. Ученые предлагают высаживать современные сорта многолетних астр - агератовидной, новоанглийской, новобельгийской, гелениум осенний, посконник пурпурный, рудбекию блестящую, калимерис вырезной и другие виды [6].

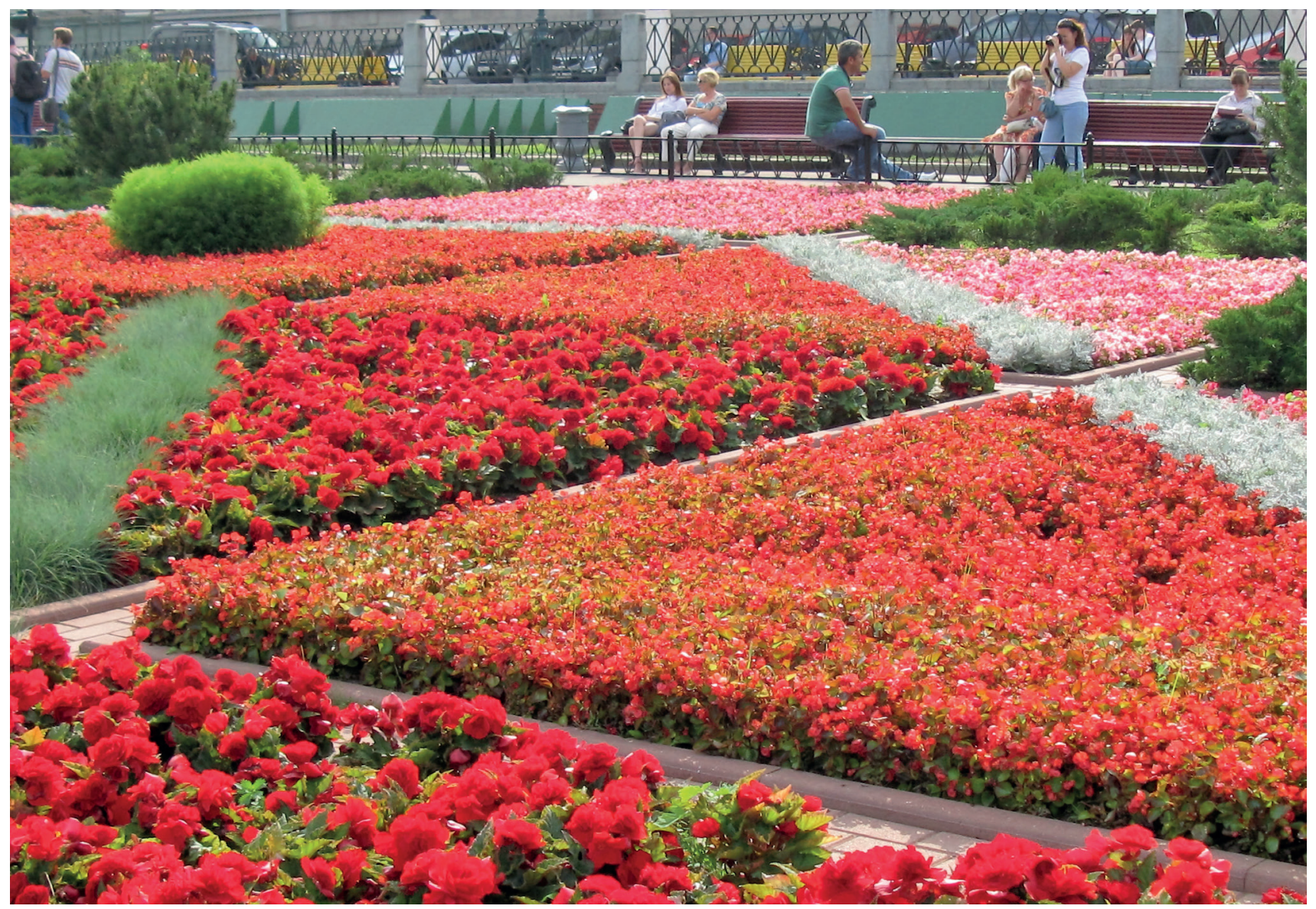

Партер из летников подходит для оформления центральных городских площадей 

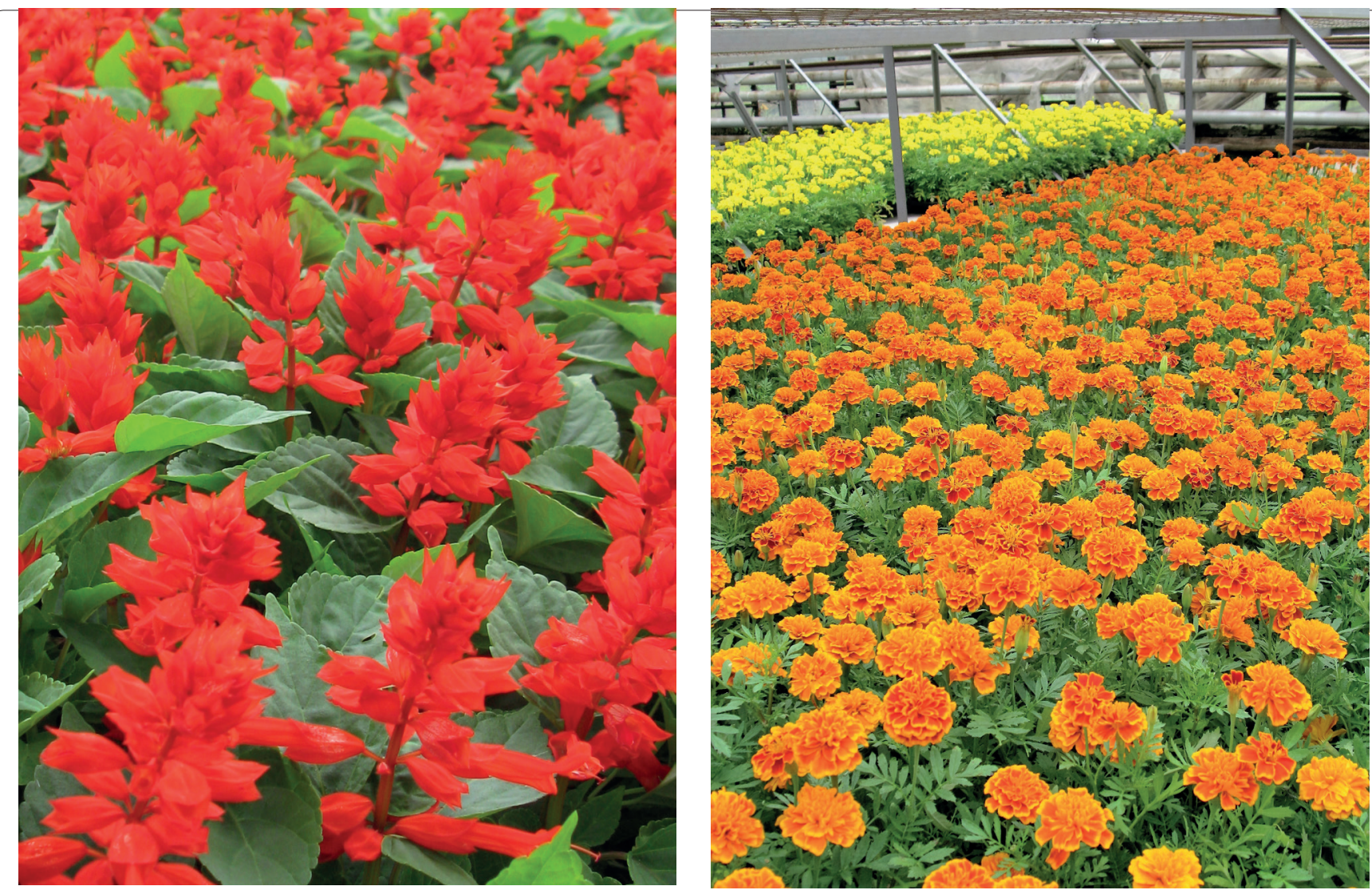

Цветущие рассады сальвии (слева) и тагетеса (спарава) готовы к посадке в городские цветники

(Ульяновский совхоз декоративного садоводства, Москва)

Сегодня в Москве, к сожалению, принято чрезвычайно дорогое, но очень однообразное цветочное оформление (огромными массивами высаживают тюльпаны, которые затем заменяют такими же массивами летников - петуний, тагетесов, сальвии и др.), хотя ученые предлагают различные, в том числе типовые, варианты озеленения. Однако специалисты Департамента ЖКХ и благоустройства Москвы практически никак не координируют свои действия с рекомендациями ученых. Так же обстоят дела и с посадкой деревьев. Мало того, что площадь зеленых массивов постоянно сокращается, но и состав древесных пород претерпевает изменения, причем далеко не в лучшую сторону.

В центральных районах Москвы практически выпал вяз, катастрофическое положение сложилось с ясенем пенсильванским (этот вид практически уничтожила изумрудная златка, завезенная с Дальнего Востока), короед-типограф продолжает уничтожать ели в Москве и Подмосковье [5]. И таких примеров можно привести множество.

В значительной степени такие явления происходят из-за пренебрежения наукой. Горе-озеленители и благоустроители действуют по своему усмотрению, не проводя экспертиз и не привлекая ученых к работам по зеленому строительству. Результаты бывают весьма плачевными. Так, во время подготовки к Олимпиаде в Сочи для озеленения города и спортивных объектов из-за рубежа было завезено большое количество посадочного материала самшита, пораженного самшитовой огневкой, - вредителем, которого здесь прежде не было. В итоге посадки самшита погибли не только в Сочи, но и на территории всего региона. Бороться обычным образом, исполь- зуя пестициды, в курортных районах недопустимо, поэтому ученые активно ищут биологические методы борьбы с этим вредителем [3], который распространился уже за пределы Черноморского побережья Кавказа. Этим летом в Грузии мне довелось видеть практически уничтоженные вредителем бордюры из самшита в Зугдиди и других городах.

Ученые активно занимаются проблемами дендрологии, исследования проводятся и в ботанических садах Москвы. Так, сотрудники Ботанического сада МГУ провели масштабное изучение пород деревьев, которые могли бы украсить улицы крупных городов, страдающих от загазованности, кислотных дождей и прочих неблагоприятных факторов. Самыми газоустойчивыми оказались ивовые и жимолостные, относительно устойчивы ясени, сирени, бирючины, форзиции, чубушники [9]. Но часто ли мы встречаем эти деревья и кустарники на наших улицах?

В Москве есть интересные примеры использования деревьев, нетрадиционных для городского озеленения. Так, в районе МГУ и около Главного ботанического сада много лет назад высадили яблони, которые вполне хорошо себя чувствуют по сей день. Конечно, плоды их несъедобны (из-за загрязнения выхлопными газами и др.), но сами деревья очень живописны, особенно в пору весеннего цветения. В районе Тимирязевской академии во внутриквартальном озеленении широко распространена смородина золотистая, декоративный кустарник с красивой ажурной листвой, приобретающей осенью огненные оттенки, и изящными желтыми цветками. Есть и другие, пока еще не очень распространенные в столице породы деревьев, которые озеленители практически не используют, например, робиния, или белая акация, 
прекрасно цветущая в конце весны и сохраняющая зеленые листья до поздней осени, красиво выделяясь на фоне деревьев с листвой, окрашенной в желтые и красные тона. И не надо говорить, что робиния южное дерево: сегодня, когда зимы в средней полосе России становятся все теплее и теплее, это растение достаточно хорошо себя чувствует в Москве и даже севернее и может представлять интерес для озеленителей. Никто сейчас не удивляется каштанам, которые давно заняли достойное место на улицах столицы, а ведь еще 40-50 лет назад они были настоящей экзотикой.

Очень хотелось бы, чтобы наука соединилась с практикой, и все разработки ученых, касающиеся использованию растений в городской среде, были приняты на вооружение специалистами благоустройства и озеленения.

Продолжая разговор о науке, стоит сказать, что свой очень важный и весомый вклад в цветоводство могут внести (и уже вносят, но пока еще очень робко) ботанические сады страны. Я имею в виду интродукцию красивоцветущих и декоративнолиственных природных видов и внедрение их в практику, то есть в озеленение. Такие работы давно и широко проводятся по всему миру. Конечно, зарубежные ученые имеют финансовые возможности для организации экспедиций в дальние страны - Австралию, Новую Зеландию, Африку, Южную Америку. Отечественные исследователи, как правило, ограничены в средствах, но Россия - такая большая и богатая природными ресурсами страна, что ученые из ботанических садов могут проводить подобные работы, не отъезжая далеко от своего города. Сибирь, Дальний Восток, Камчатка, Курильские острова - неистощимый

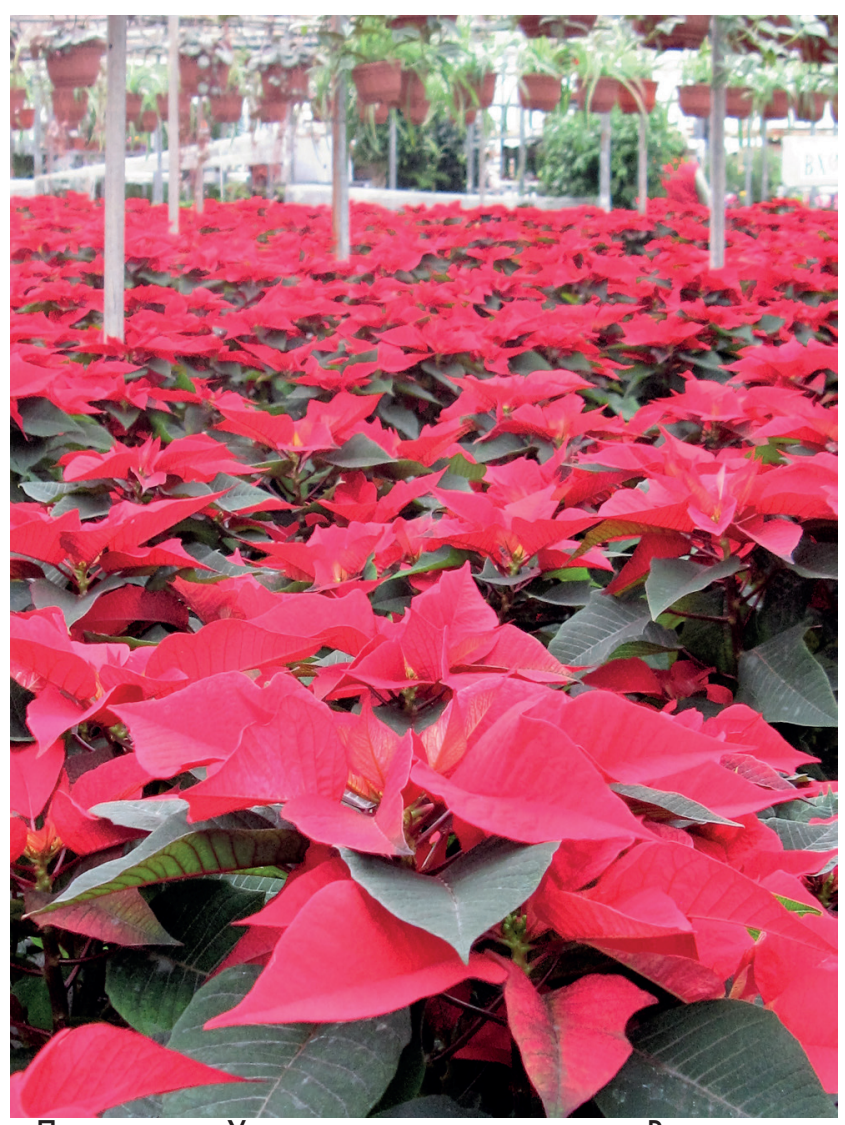

Пуансеттию в Ульяновском совхозе готовят к Рождеству и Новому году источник новых перспективных культур, достойных не только украсить улицы и площади наших городов, но и стать предметом экспорта. Об этом еще в начале 40-х гг. прошлого века писал замечательный ученый и практик, профессор Д.Д. Арцибашев (неправедно осужденный по пресловутой 58-й статье и погибший от голода в 1942 г., одновременно с Н.И. Вавиловым, в той же Саратовской тюрьме) в своей книге «Декоративное садоводство»: «Селекиионная работа в декоративном садоводстве открывает перед нами замечательные перспективы. Блестящзие успехи по превращению скромных дикорастущчих видов в роскошно иветушие представители самых богатых партеров, достижения по переделке окраски изветов, особенно у многолетников, по приданию аромата, удлинению (в 2-3 раза) ияветоносных стержней, управлению не только размерами цветка, но и "загущением” бутонов, изменением очертания лепестков, улучшением контуров куста - все эти успехи со временем могут быть еще более значительны. Для этого необходимо лишь, чтобы селекиионное дело в области декоративного садоводства... стало подлинно научным. Наряду с этим необходимо, чтобы декоративные свойства растений, которыми так бесконечно богата наша страна, были предметом внимания наших многочисленных экспедиций и ботанических садов» [1].

Но если мы обладаем таким богатством, то почему же до сих пор природные виды практически не встречаются на городских клумбах и рабатках (исключением здесь могут быть только цветники отдельных коллекционеров-любителей)? Ответить на этот вопрос достаточно просто: все дело в том, что на Западе подобные работы стоят на потоке и проводятся в

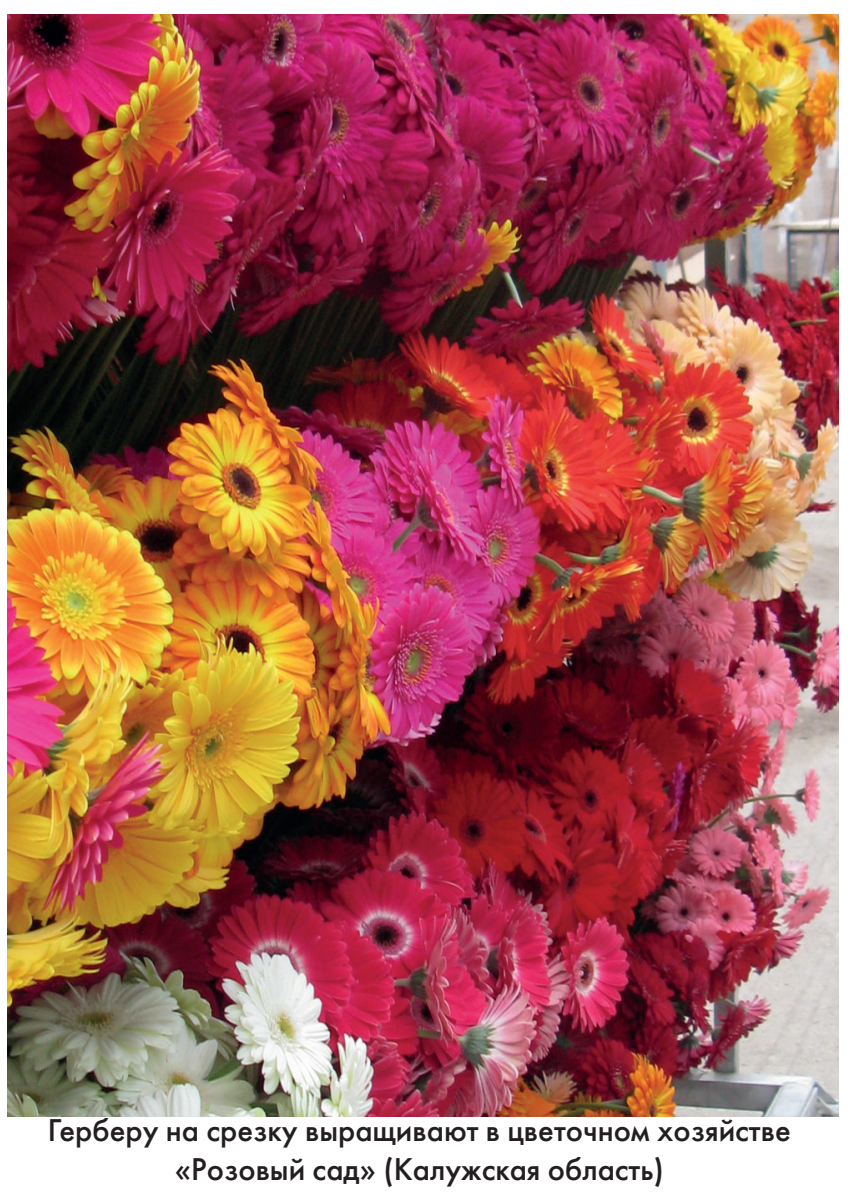


сотрудничестве, во-первых, с селекционными фирмами, куда перспективные природные растения с высоким декоративным потенциалом передаются сразу после интродукции и изучения ботаниками и где на их основе создаются новые высокодекоративные, устойчивые к неблагоприятным факторам окружающей среды сорта, а во-вторых, с цветочными хозяйствами, которые размножают эти сорта. У нас таких цепочек не выстроено, поэтому даже если ботаники привозят из экспедиций интересные и перспективные растения местной флоры, то они в лучшем случае остаются в коллекциях научных учреждений и дальше не продвигаются. Разрозненность исследований, слабая материальная база, недостаточность финансирования, а главное, отсутствие общей стратегии развития цветоводства в стране в целом и цветоводческой науки в частности препятствуют выходу отрасли на современный уровень и ее конкурентоспособности с импортной продукцией.

Скажу еще несколько слов о селекции цветочных культур - одном из важных направлений деятельности научных учреждений. В советское время выведению новых сортов декоративных культур уделялось большое внимание. К примеру, селекцией роз занимались ученые в Главном ботаническом саду АН CССР, Ботаническом саду АН Казахстана, Ботаническом саду АН Латвии, Никитском ботаническом саду и др. Сегодня новые сорта роз активно создаются, пожалуй, только в последнем: работу известного селекционера Веры Николаевны Клименко с успехом продолжает ее дочь, доктор биологических наук Зинаида Константиновна Клименко. Выведенные ими розы ('Климентина', 'Бахчисарайский Фонтан', 'Артек’, ‘Аджимушкай', 'Аю-Даг' 'Никитский Юбилей’, 'Лезгинка' и многие-многие другие) украшают парки и улицы городов Крыма. В этом же ботаническом саду занимаются, причем весьма успешно, селекцией хризантем, канн, клематисов и других декоративных культур. К тому же здесь уже давно и активно проводятся биотехнологические исследования, в том числе работы по клональному микроразмножению и оздоровлению растений, без которых нельзя сегодня серьезно заниматься селекцией $[9,12]$. Продолжаются работы по выведению новых сортов древовидных пионов в Ботаническом саду МГУ, хризантем в Дальневосточном саду-институте ДВО РАН, лилий и гладиолусов во Всероссийском институте садоводства им. И.В. Мичурина и др.

Однако в масштабах страны таких работ явно недостаточно. В общем и целом, дела с созданием отечественных сортов декоративных растений обстоят далеко не благополучно. Даже если исследования ведутся, дальнейшая судьба выведенных сортов остается весьма неопределенной. Так, в одном из научных институтов, претендующем на ведущую роль в цветоводческой науке, созданы неплохие сорта фрезии. Но когда зашла речь о внедрении их в производство, оказалось, что институт не может предоставить посадочный материал этих сортов, его просто нет (или очень мало), потому что опытное хозяйство, которое должно было бы заниматься размножением новых культиваров, разрушено, и там можно выращивать только лук и укроп, которым не нужно ни отопление, ни дополнительное освещение, ни остекление. И в этом нельзя обвинить руководство научного учреждения - все это следствие упадка науки в 90-е гг.

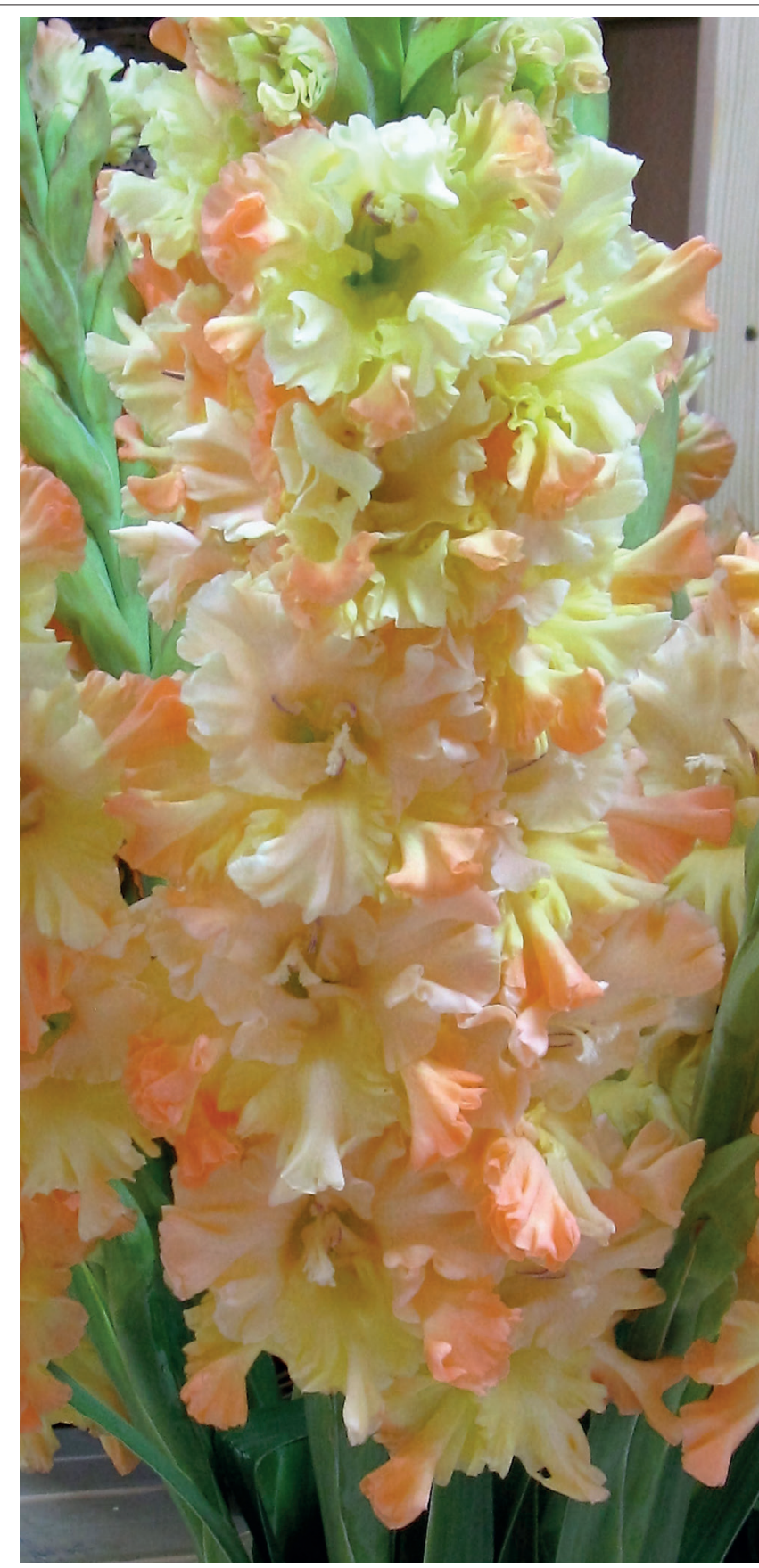

Гладиолус сорта 'Великая Княгиня Елизавета' (селекционер М.А. Кузнецов)

прошлого века и недостаточного ее финансирования во все последующие годы вплоть до сегодняшнего дня. Хотя, справедливости ради, стоит сказать, что от инициативности руководства тоже зависит немало. В качестве положительного примера приведу Никитский ботанический сад, который проводит многочисленные праздники и фестивали - тюльпанов, ирисов, роз, хризантем, привлекая таким образом посетителей и зарабатывая деньги. Так же действует и филиал Ботанического сада МГУ «Аптекарский огород», где в течение года проходят не только всевозможные фестивали и сезонные праздники цветов, но и столь модные сегодня в мире концерты «ореп air» классической и джазовой музыки. Действительно, по-видимому, надеяться можно только на себя, потому что ждать милостей от государства в лице ФАНО не приходится. 
Говоря об отечественной селекции, нельзя не сказать о вкладе оригинаторов-любителей, которые еще в 30-е гг. прошлого века начали активно и успешно заниматься выведением новых сортов декоративных культур. Сирень Л. А. Колесникова, флоксы П.Г. Гаганова, георгины Б.Я. Алишоевой, А.Н. Сидоровой, И.Н. Нессоновой, В.М. Суханова, клематисы М.Ф. Шароновой, гладиолусы А.Н. Громова, М.А. Кузнецова, В.Ф. Дыбова и многих других, ирисы и гладиолусы Н.А. Мирошниченко (этот список можно долго продолжать) до сих пор высоко ценятся коллекционерами и широко выращиваются в России и странах СНГ. К большому сожалению, в сферу интересов научных учреждений эти сорта попадали редко, в лучшем случае их включали в коллекции тех или иных декоративных культур. Мне это кажется большой ошибкой, потому что многие сорта, созданные селекционерами-любителями, заслуживают пристального внимания и дальнейшей работы [15]. Приходится признать, что в последние годы резко сократилось число оригинаторов, занимающихся гладиолусами и георгинами, которых еще недавно было очень много. И не только оригинаторов, но и коллекционеров, и цветоводов, выращивающих эти культуры на продажу. Такое катастрофическое положение связано со многими факторами, но, главным образом, с запретительными мерами, предпринимаемыми местными властями. Цветоводов практически полностью лишили возможности продавать выращенные ими цветы. Магазины и флористические фирмы в большинстве случаев предпочитают работать с импортной продукцией, им неинтересны малые партии цветов, пусть даже самых роскошных. А раз у цветовода нет возможности продать цветы, то

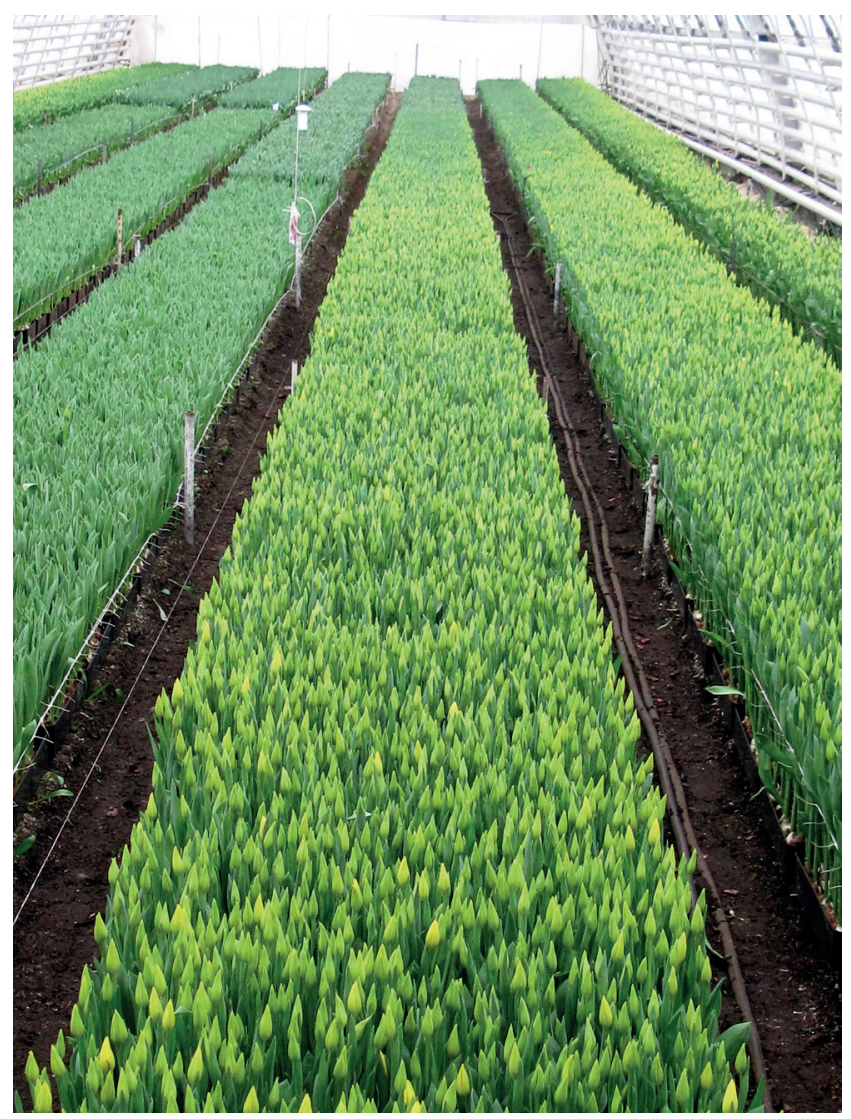

Теплица с тюльпанами в «Галантусе» (Калуга) нет спроса на посадочный материал традиционных и новых сортов. Время уходит, многие культивары утеряны, и часто это - утраты невосполнимые

Стоит сказать здесь еще об одной культуре, которой активно занимаются любители. Это очень популярное комнатное растение - узамбарская фиалка, или сенполия. Ее судьба оказалась счастливее других. Благодаря деятельности В.Н. Калгина, большого почитателя этого изящного растения, энтузиаста и мецената, созданные в стране сорта сенполии не только завоевали любовь на родине, но и покорили сердца заокеанских цветоводов. Российские сорта уже не раз завоевывали высокие награды на самых престижных выставках в США и Канаде [7]. Но у ученых, несмотря на все усилия В.Н. Калгина, интереса к отечественным фиалкам не замечено. А в цветочных хозяйствах, если и выращивают сенполии, то самые простые, старые сорта, не проявляя интереса к отечественным, очень эффектным новинкам.

Все невнимание и незаинтересованность в развитии любительской селекции, ее игнорирование большой наукой (вместо того чтобы умело и с пользой включать ее в общий процесс создания новых сортов) следствие той же проблемы, о которой говорилось выше, - отсутствия какой бы то ни было общей стратегии развития цветоводства в стране.

\section{Россия vs Голландия: утопия или реальность?}

O проблемах науки можно говорить еще долго, но я здесь поставлю точку и перейду к главной составляющей цветоводства - хозяйствам, выращивающим и поставляющим в торговую сеть срезанные цветы, комнатные растения и посадочный материал

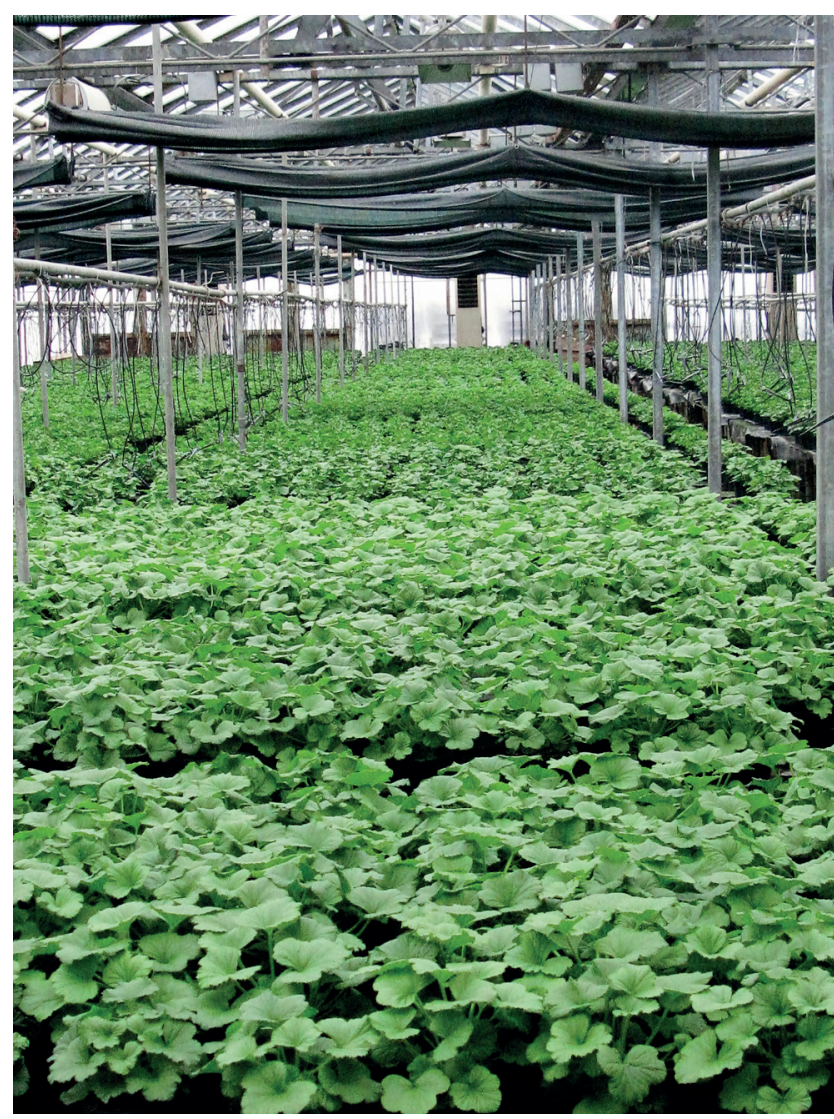

Любимая всеми пеларгония весной перекочует из теплиц в городские цветники, уличные контейнеры и на балконы 
декоративных культур. Их достаточно много, среди них есть государственные и частные предприятия. Первые обычно относятся к сфере городского благоустройства и должны, среди прочего, выращивать рассаду цветочных и древесных культур для городского озеленения. К примеру, в Москве они относятся к ГБУ «Озеленение» (раньше ГУП «Мосзеленхоз»). Среди них есть более и менее успешные, оснащенные современными теплицами и оборудованием, и старые, нуждающиеся в реконструкции. Они специализируются на рассаде летников, горшечной продукции или выращивают розы, лилии, хризантемы и другие культуры на срезку.

Что касается цветочной рассады, то сегодня для нужд городов ее производят в основном на месте, хотя семена, укорененные или неукорененные черенки для ее выращивания закупают преимущественно за рубежом. Это большие затраты, особенно сегодня, при высоком курсе доллара и евро. Однако для производства посадочного и посевного материала в России практически ничего не делается, и это возвращает нас к проблемам науки (семеноводство, клональное микроразмножение и др.) и снова к отсутствию общей концепции развития цветоводства в стране.

Многие цветочные хозяйства специализируются на выращивании срезочной цветочной продукции. В последние годы появилось немало крупных современных предприятий, производящих розы - самую востребованную срезочную культуру в нашей стране («Розовый сад», «Чеховский сад», «Новая Голландия», «Моршанский тепличный комплекс», «Розы Подмосковья» и др.). Однако несмотря на это, в стране выращивается едва ли 5\% общего количества продаваемых срезанных цветов. И вопрос о том, нужно ли у нас выращивать цветы на срезку, а если нужно, то какие, - не сходит с повестки дня.

Дело в том, что производство срезки цветов - дело весьма затратное, поскольку получить качественные цветы невозможно без обогрева теплиц и досвечивания растений. Зима у нас темная и длинная, и без серьезных энергозатрат не обойтись. Цветочные хозяйства, в отличие от тепличных комбинатов, выращивающих овощи, не получают государственных дотаций на свет и газ. Поэтому себестоимость отечественных цветов достаточно высокая, а хозяйства зачастую оказываются «в долгах, как в шелках» - за электричество, газ и др.

Вопрос о том, надо ли в отечественных хозяйствах выращивать розы, лилии, хризантемы и другие цветы, по сей день остается открытым. Конечно, нет никаких сомнений, что роза, выращенная в московском или подмосковном хозяйстве, у жителя столицы простоит в вазе дольше, чем колумбийская или эквадорская, преодолевшая огромный путь через океан. Однако цена ее, скорее всего, будет такой же, а по сравнению, к примеру, с кенийской розой, при выращивании которой в теплицах не нужен ни обогрев, ни дополнительное досвечивание, даже выше. Так нужно ли производить срезанные цветы или проще закупать их за рубежом?

Отрицательно ответили на этот вопрос цветоводы Финляндии - страны со схожими климатическими условиями. После вступления в Общий рынок они практически полностью отказались от собственного производства срезанных цветов, хотя до этого выра-

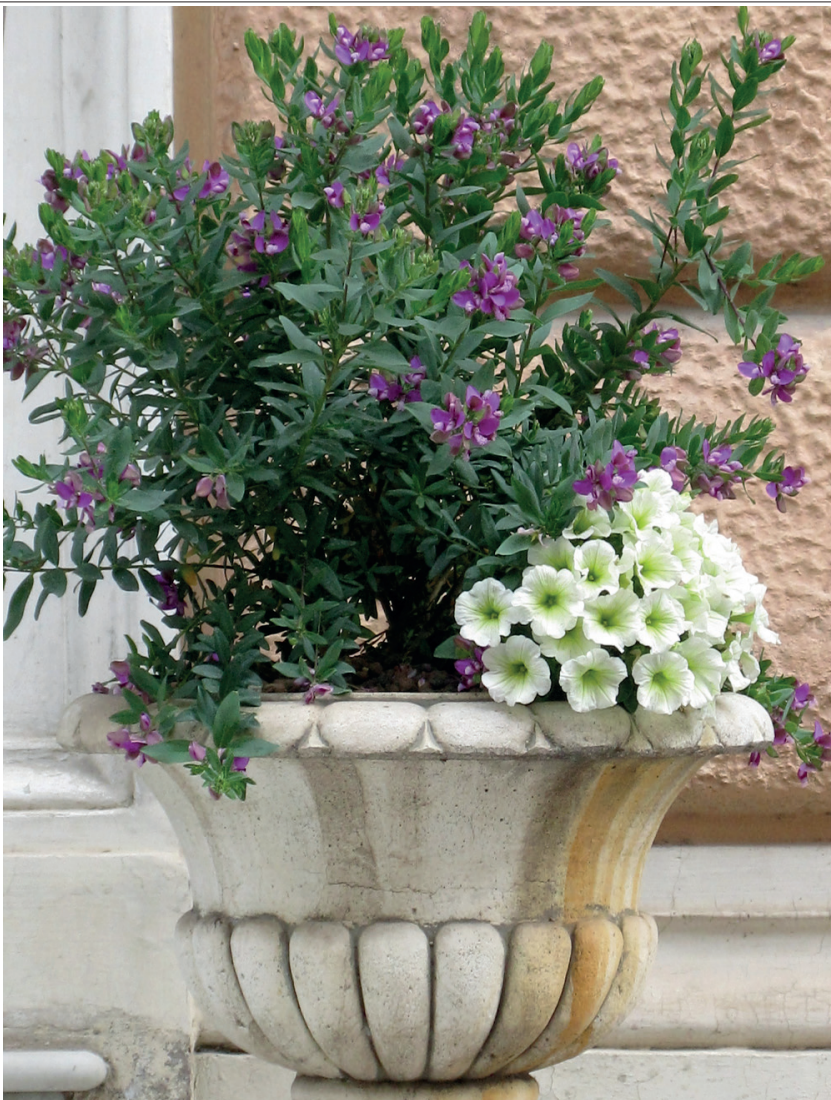

Истод миртолистный - южноафриканский вид, совсем недавно введенный итальянскими учеными

в культуру, уже широко используется в озеленении, украшая улицы Рима (в вазоне с петунией)

щивали прекрасные розы и многие другие культуры. Но конкуренции с импортными цветами, заполонившими рынок страны, они не выдержали - ни по цене, ни по сортовому разнообразию, ни по качеству.

Так что же - закрывать недавно построенные современные тепличные комбинаты или переводить их на выращивание огурцов? И здесь мы опять упираемся в проблему координации науки с производством (невольно вспоминается советский лозунг «Достижения науки - в производство!»). Необходимо подобрать культуры, не требующие больших энергозатрат, разработать технологии их выращивания и внедрить в производство. И это, без всяких сомнений, одна из важнейших задач цветоводческой науки. Об этом уже давно писал проф. Д.Д. Арцибашев: «Мы должны стремиться к тому, чтобы наиболее полно использовать энергию солнца, а при культуре под стеклом добиваться возможно меньшего расхода топлива» [1].

В России сегодня с успехом выращивают тюльпаны - одну из самых выгодных культур, которая не требует досвечивания и высокой температуры в теплицах. Существуют технологии их выращивания на питательном растворе без грунта. Ящики с луковицами можно держать даже в необорудованных коридорах теплиц. Во многих российских хозяйствах к 8 Марта получают большие урожаи срезки тюльпанов самых разных сортов, обеспечивая при этом высокую прибыль. К сожалению, луковицы приходится закупать в Голландии, а их цена из-за значительно выросшего курса евро увеличилась почти вдвое, что 
обусловило повышение стоимости срезки. Раньше в южных регионах страны работали хозяйства, в больших количествах производящие посадочный материал луковичных культур - тюльпанов, нарциссов, гиацинтов (например, «Мир» в Крыму). Сегодня в России нигде этим не занимаются, и это опять вопрос отсутствия программы развития отечественного цветоводства.

К сожалению, кроме тюльпанов, другие малоэнергоемкие культуры у нас практически не выращиваются. А ведь их довольно много, например, летники тагетес, агератум, антирринум, годеция, турецкая гвоздика, астра китайская (список можно продолжить), многолетники - нивяник, василек, флокс и др. Современные их сорта очень эффектны и вполне могут конкурировать с традиционными срезочными растениями. Большинство из них с успехом культивируют в Голландии и других западных странах. В России опыт выращивания таких культур есть, пожалуй, только в одном хозяйстве. Это известный на всю страну калужский «Галантус» (ОАО), где благодаря директору Ю.В. Казанкову и главному агроному Л.С. Казанковой не только выращиваются лучшие в стране цветы, но и проводятся экспериментальные работы по внедрению в культуру новых для отечественных хозяйств растений - антирринума, трахелиума, тагетеса, гладиолуса и др. Кроме того, здесь выращивают и испытывают новейшие сорта нарциссов, тюльпанов, лилий, роз, хризантем. «Галантус» тесно сотрудничает с селекционными фирмами Голландии, здесь часто бывают специалисты из этой страны. Хозяйство оснащено современными, укомплектованными новейшим оборудованием теплицами. Сюда в феврале на ежегодную выставку к дню Святого Валентина приезжают цветоводы из всех уголков страны, чтобы познакомиться с опытом работы калужан, посмотреть на новые сорта и культуры [17].

«Галантус» вполне мог бы работать в тесном комплексе с научными учреждениями, осуществляя

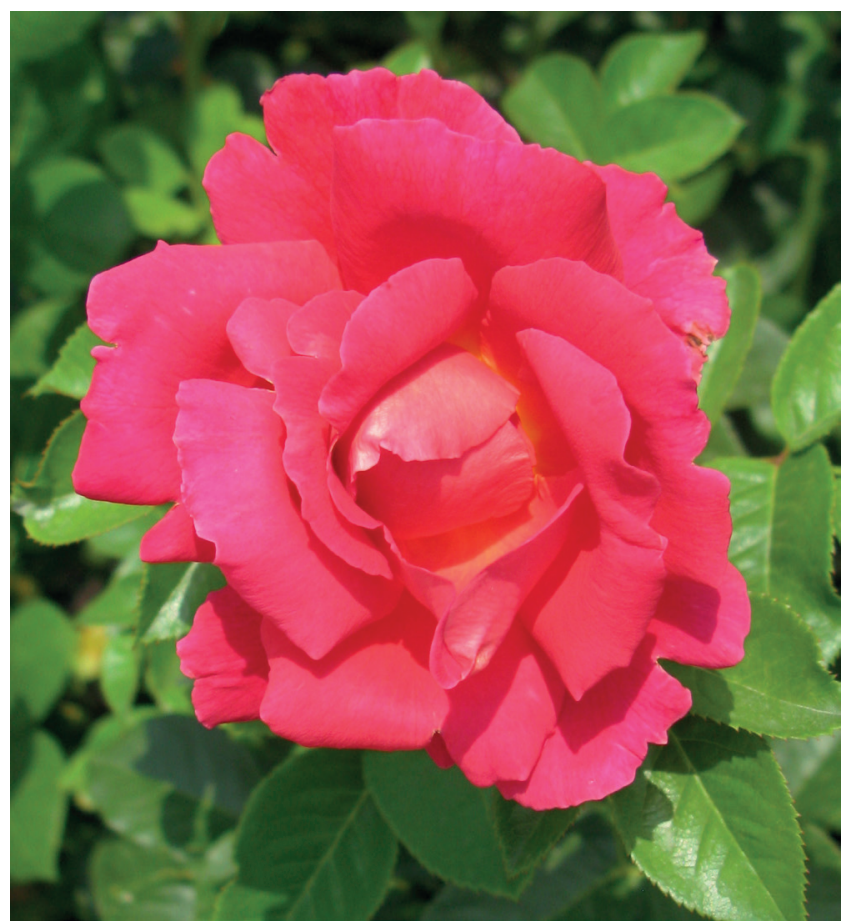

Роза 'Никитский Юбилей' (селекционер 3.К. Клименко) выведена к 200-летию Никитского ботанического сада (2012 г.) связь науки с производством, о которой выше уже много было сказано. Для этого здесь есть все - и современные производственные площади, и квалифицированные кадры, и большой опыт. У «Галантуса» были планы объединения с Всероссийским институтом садоводства им И.В. Мичурина, где традиционно проводятся исследования по многим цветочным культурам - лилиям, гладиолусам, астрам и др. Но, к сожалению, по ряду объективных причин им не суждено было осуществиться. Но если вдруг когда-нибудь будет разработана комплексная программа развития цветоводства, хотелось бы, чтобы потенциал «Галантуса» был в ней учтен и использован.

Практически изолированно живут и работают частные цветочные хозяйства, например, расположенные на юге России и в Крыму. Я имею в виду не дачников, выращивающих на своих шести сотках цветы на продажу, а относительно крупные фермерские хозяйства, которые производят цветы, по качеству зачастую не уступающие импортной продукции. Мы много говорим об импортозамещении, но разве часто можно встретить эти цветы в магазинах крупных российских городов? Мне известен лишь один московский оптовый торговец, закупающий некоторые (не все) сорта эустомы, георгин, нивяника у крымских цветоводов. Поэтому они вынуждены по ночам привозить свои цветы на стихийный оптовый рынок в центре Симферополя в надежде, что кто-то приедет и купит выращенную ими продукцию (надо отметить, что после перехода Крыма к России положение цветоводов полуострова значительно ухудшилось, поскольку раньше большая часть их цветов уходила в Украину, в частности, в Донецк и Луганск, а сегодня Украина для них закрыта, а Россия, к сожалению, не очень открыта). Никто серьезно не интересуется этими цветами, не уверена даже, что все оптовики знают о них [16].

Что препятствует развитию цветоводства как малого бизнеса на юге России, да и не только там, но и

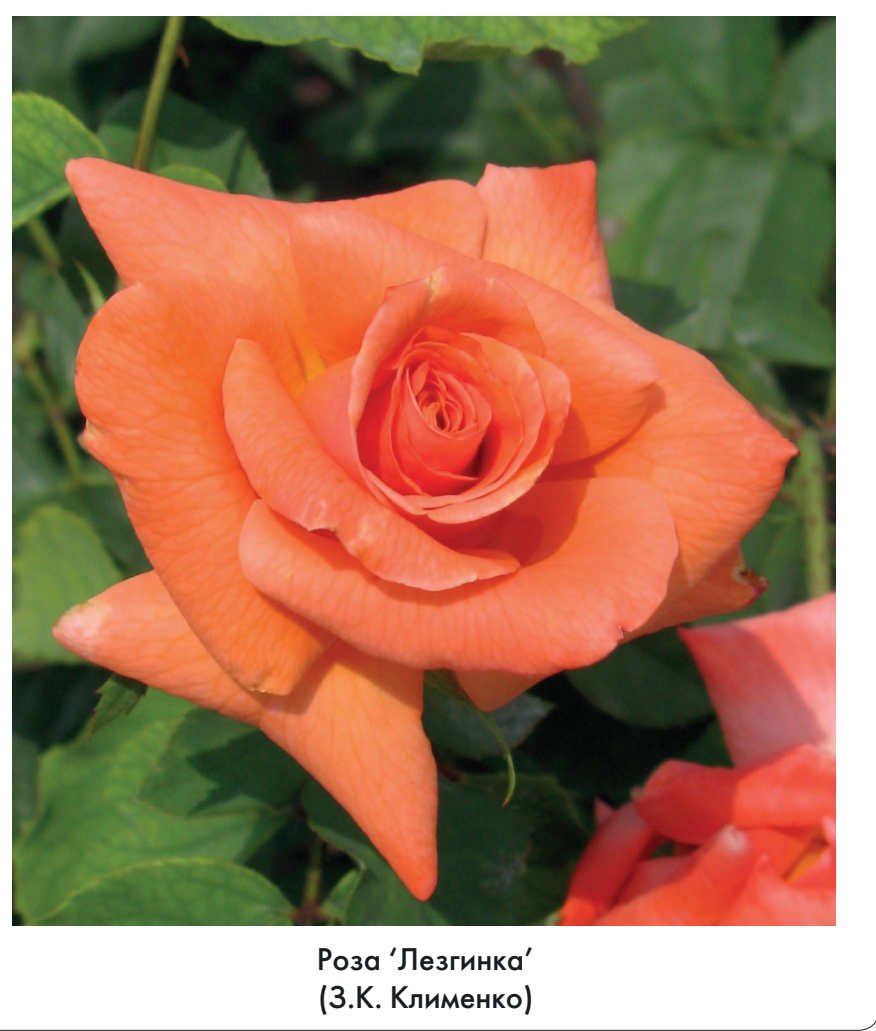




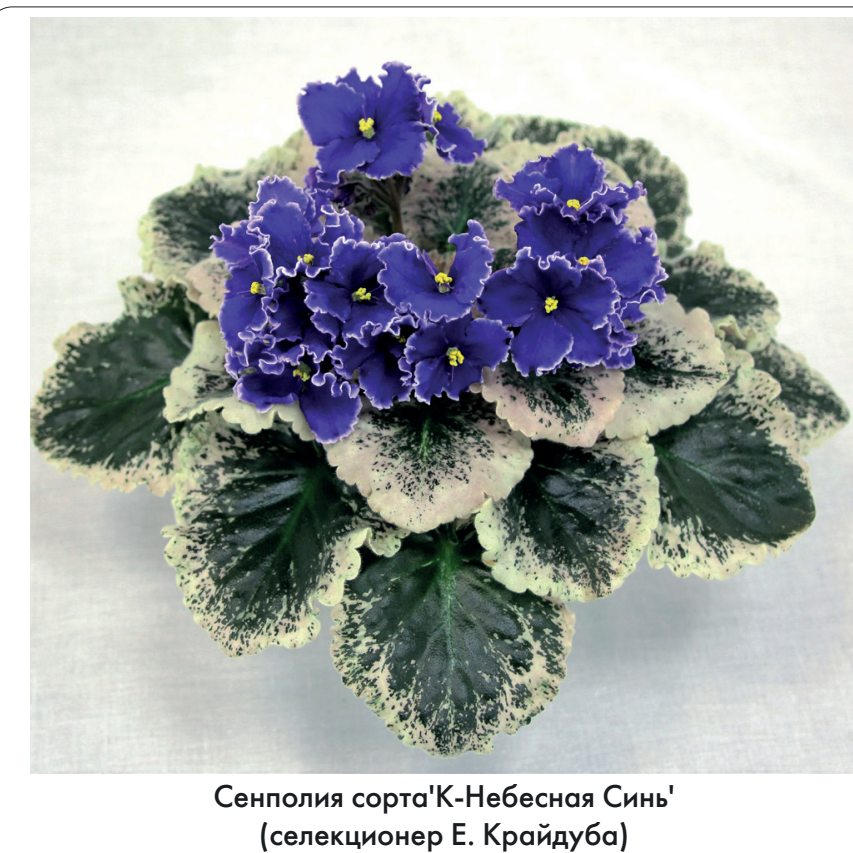

в других регионах? Причины известны - это наши извечные дураки и дороги, вернее, присутствие первых и отсутствие вторых. В каждой шутке есть доля правды, и главный фактор, сдерживающий развитие, - отсутствие сбыта, его непредсказуемость, что напрямую связано с дорогами и логистикой. И об этом много лет назад писал проф. Д.Д. Арцибашев: «Одним из главных условий успеха заложения наиболее иенных культур... в наших субтропиках является надлежашее приспособление транспорта и упаковки и обеспечение дальнейшего хранения (временного) получаемой продукиии» [1]. Не хочется повторяться, но, тем не менее, здесь мы вновь сталкиваемся с разобщенностью российского цветоводства.

Следствие этой разобщенности - отсутствие программы по развитию цветочного производства на юге России. Д.Д. Арцибашев своей книге «Декоративное садоводство» обращает особое внимание на решающую роль русской Ривьеры - Черноморского побережья Кавказа и Крыма, где климат благоприятствует выращиванию многих культур как на срезку, так и для получения посадочного материала, в снабжении северных регионов цветами для самых разных нужд. Работу по созданию и координированию такой программы мог бы возглавить Всероссийский институт цветоводства и субтропических культур (Сочи), который сегодня работает в этом направлении, но не может делать это в полную силу из-за недостаточного финансирования $[8,11]$.

\section{Нет ведомства - нет отрасли?}

Скажу несколько слов о том, как существовало цветоводство раньше, в советское и постсоветское время (примерно до 2000-х). Цветоводство как отрасль курировало Министерство сельского хозяйства СССР, и хотя, конечно, внимание этой отрасли уделяли в последнюю очередь, поскольку надо было выполнять более важные задачи (Продовольственная программа, постоянные битвы за урожай и др.), тем не менее, какие-то вопросы развития цветочного производства можно было худо-бедно решить (или не решить) на высоком уровне. Помимо этого, существовал павильон «Цветоводство и озеленение» на ВДНХ (основан-

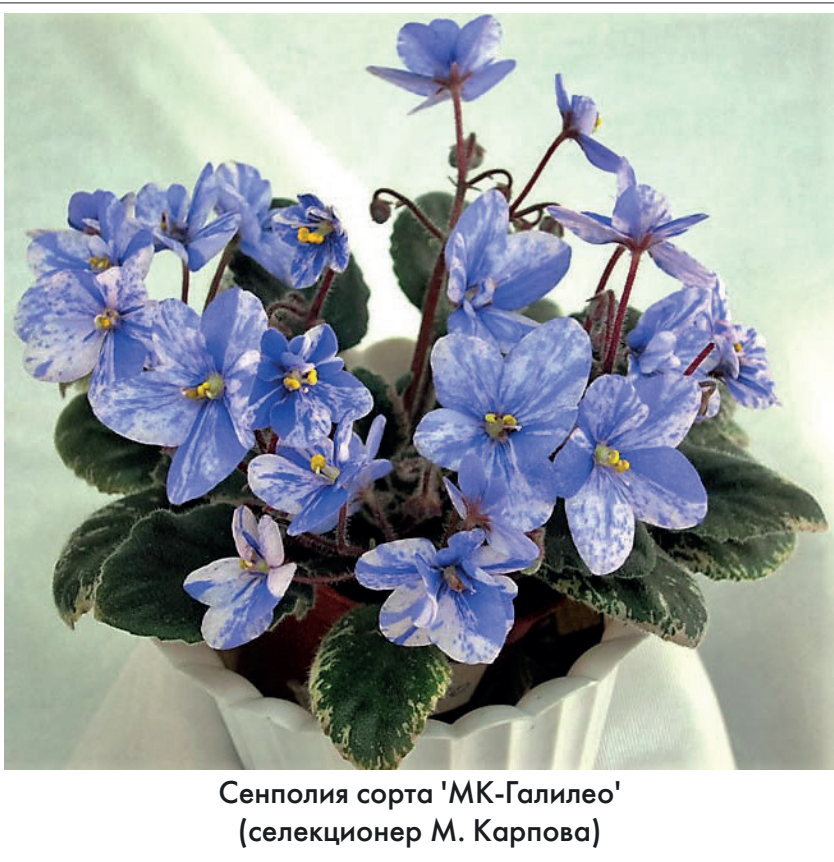

ный в 1955 г.), в котором работали высокопрофессиональные специалисты под руководством энтузиаста отрасли К.А. Севастьяновой и где регулярно проводились совещания, семинары, выставки, целью которых было познакомить профессионалов и любителей с достижениями отрасли, новыми технологиями, селекционными достижениями. Сюда для обмена опытом, профессиональной учебы приезжали работники цветочных хозяйств, питомников, научных учреждений не только из крупных центров страны, но и из самых отдаленных регионов. Сегодня, к большому сожалению, павильон «Цветоводство и озеленение», хотя номинально и существует (в нем проводятся лекции для цветоводов-любителей, но в основном его площади отданы под розничную торговлю посадочным материалом и товарами для садоводов), прежних своих многочисленных функций не выполняет.

В 1958 г. начал выходить всесоюзный журнал «Цветоводство», призванный решать эти же задачи и сразу же завоевавший огромную популярность (тираж доходил до 500000 экземпляров). В его создании огромную роль сыграли выдающиеся ученые, в том числе доктора биологических наук Н.А. Базилевская и С.Г. Сааков, канд. сельскохозяйственных наук В.В. Вакуленко, канд. биологических наук Н.П. Николаенко, возглавившая журнал. На долгие годы «Цветоводство» стал единственным изданием, освещавшим вопросы науки, производства, озеленения, селекции, флористики, любительского цветоводства. Сотрудники редакции имели возможность ездить по стране, посещать лучшие цветочные хозяйства, знакомиться с озеленением городов в разных регионах и освещать достижения ведущих цветочных комбинатов в журнале. После 2000 г. появилось много новых журналов по декоративному садоводству, но все они были, в основном, предназначены для любителей. Журнал «Цветоводство» был единственным изданием, включенным в список ВАК, где аспиранты, докторанты, ученые могли публиковать результаты своих исследований. К сожалению, в середине 2015 г. журнал, который всегда существовал только на собственные средства, перестал выходить из-за отсутствия денег на его издание. Кризис, охвативший страну, 
не мог не сказаться на жизни журнала - снизились подписка и розничные продажи, уменьшилось количество рекламы (у производственников - тоже кризис), постоянно росли цены на полиграфию и аренду скромного помещения, занимаемого редакцией. Несмотря на усилия сотрудников, которые были готовы работать без зарплаты, невзирая на обращения в различные министерства и ведомства, призывы к частному бизнесу, - ни у кого не нашлось денег на спасение журнала.

Таким образом отрасль лишилась последних опор, оставшись без поддержки профессионалов из павильона «Цветоводство и озеленение» и журнала «Цветоводство». Здесь стоит вспомнить крылатую фразу, часто произносимую в советское и постсоветское время: «Нет ведомства - нет отрасли». Так вот для цветоводства она, к сожалению, ярко отражает сегодняшнее состояние дел.

\section{Развитие питомниководства: основание для осторожного оптимизма}

Но говорить только о недостатках - неправильно. Да и не бывает так, чтобы все было совершенно беспросветно. В рамках статьи нельзя не упомянуть о таком отрадном явлении, как бурное развитие отечественного питомниководства, которое, несомненно, имеет прямое касательство к цветоводческой отрасли. В 2008 г. создана Ассоциация производителей посадочного материала (АППМ), объединившая владельцев частных питомников по всей России. Сегодня эта некоммерческая организация включает 167 питомников из 36 субъектов Российской Федерации, а также питомники Белоруссии, Казахстана и Украины. Общая площадь, занимаемая питомниками, входящими в АППМ, - около 9000 га. Главные задачи,

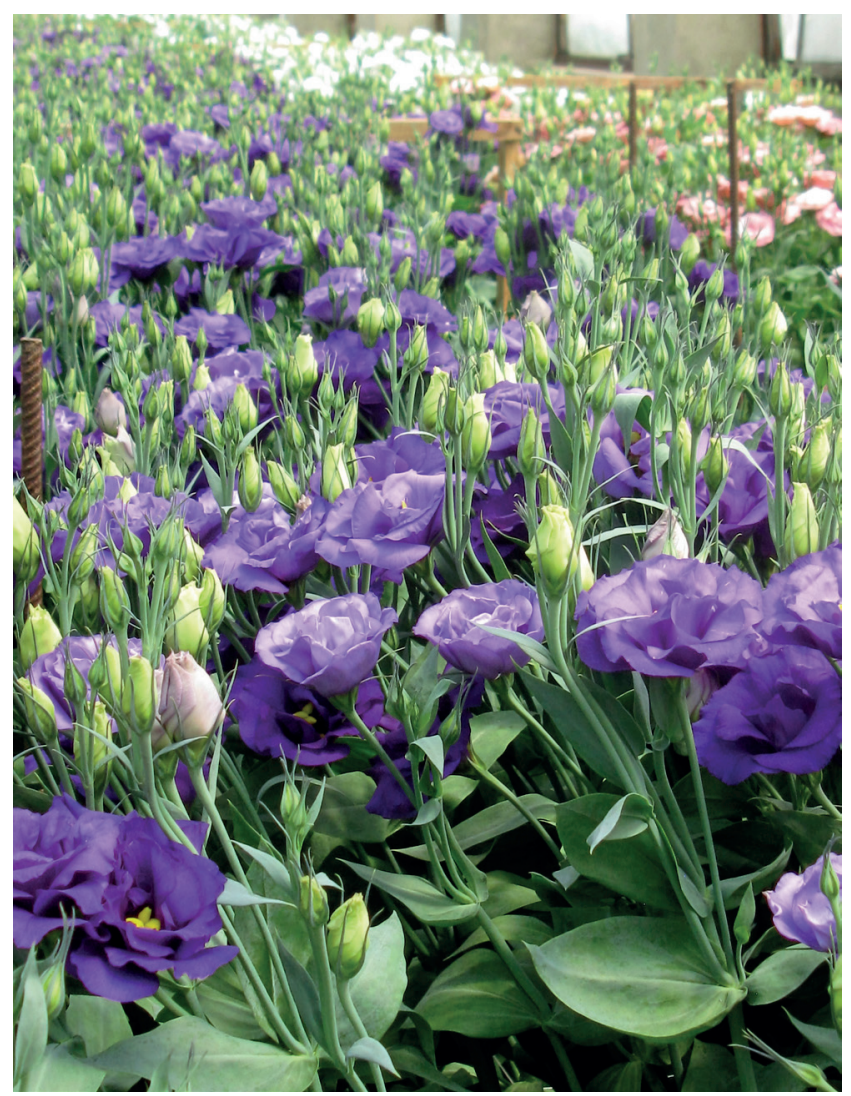

Эустома, выращенная в Крыму в легких теплицах, по качеству не уступает голландской

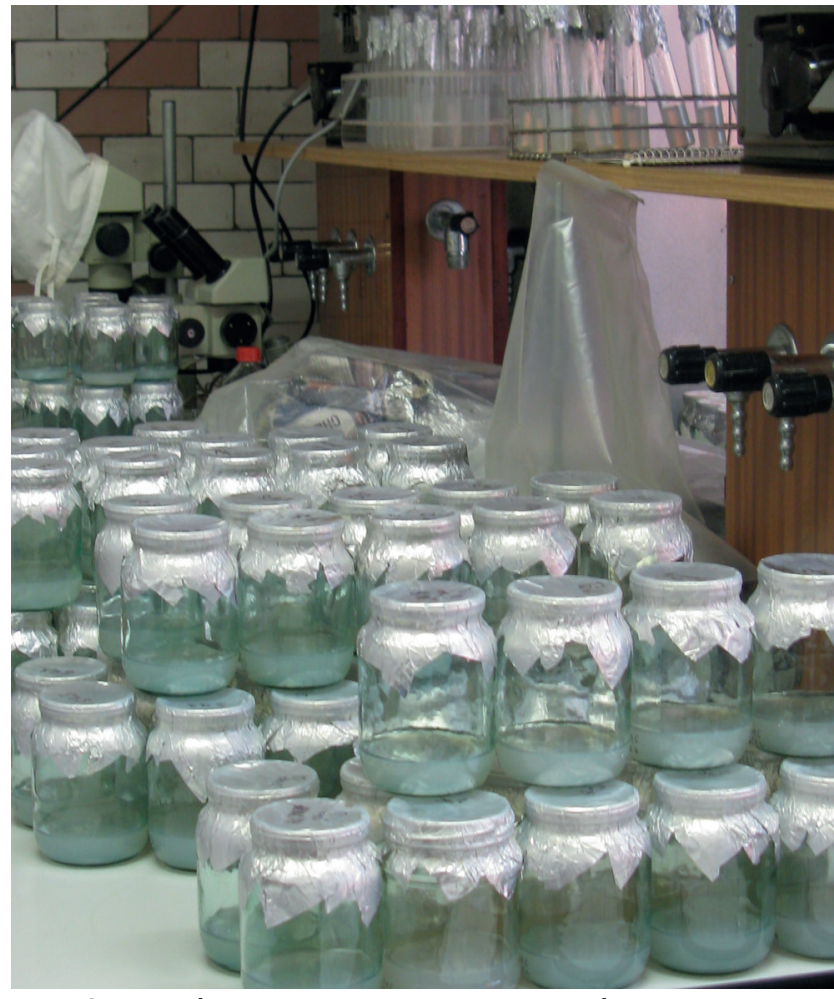

В Отделе биологии развития растений, биотехнологий

и биобезопасности Никитского ботанического сада проводятся работы по оздоровлению растений

и клональному размножению редких и исчезающих видов

которые должна решать Ассоциация, сформулированы в следующем порядке:

- обмен информацией между питомниками;

- внедрение современных технологий производства посадочного материала;

- продвижение отраслевых стандартов на посадочный материал;

- издание каталогов растений (многолетников, древесных, плодовых);

- диалог с государственными и контролирующими органами для совершенствования норм и правил работы питомников;

- организация поездок по обмену опытом в российские и зарубежные питомники;

- международное сотрудничество.

Ассортимент декоративных древесных и травянистых растений, производимых в этих питомниках, год от года растет, причем выращиваются новые, самые популярные и востребованные сорта. Питомниководы сумели объединиться на взаимовыгодных условиях: они обмениваются опытом, посещая лучшие питомники России и мира, проводят научные конференции, участвуют в выставках, тесно сотрудничают с крупнейшими ландшафтными фирмами страны. Их слаженная и активная работа привлекла даже внимание Министерства сельского хозяйства страны, что несомненно очень отрадно, поскольку деятельность АППМ заслуживает заинтересованного отношения, а их опыт следует учесть при создании программы развития отечественного декоративного садоводства.

Мое разыгравшееся воображение уже рисует радужные картины сотрудничества питомников и научных учреждений. Сначала приведу несколько 


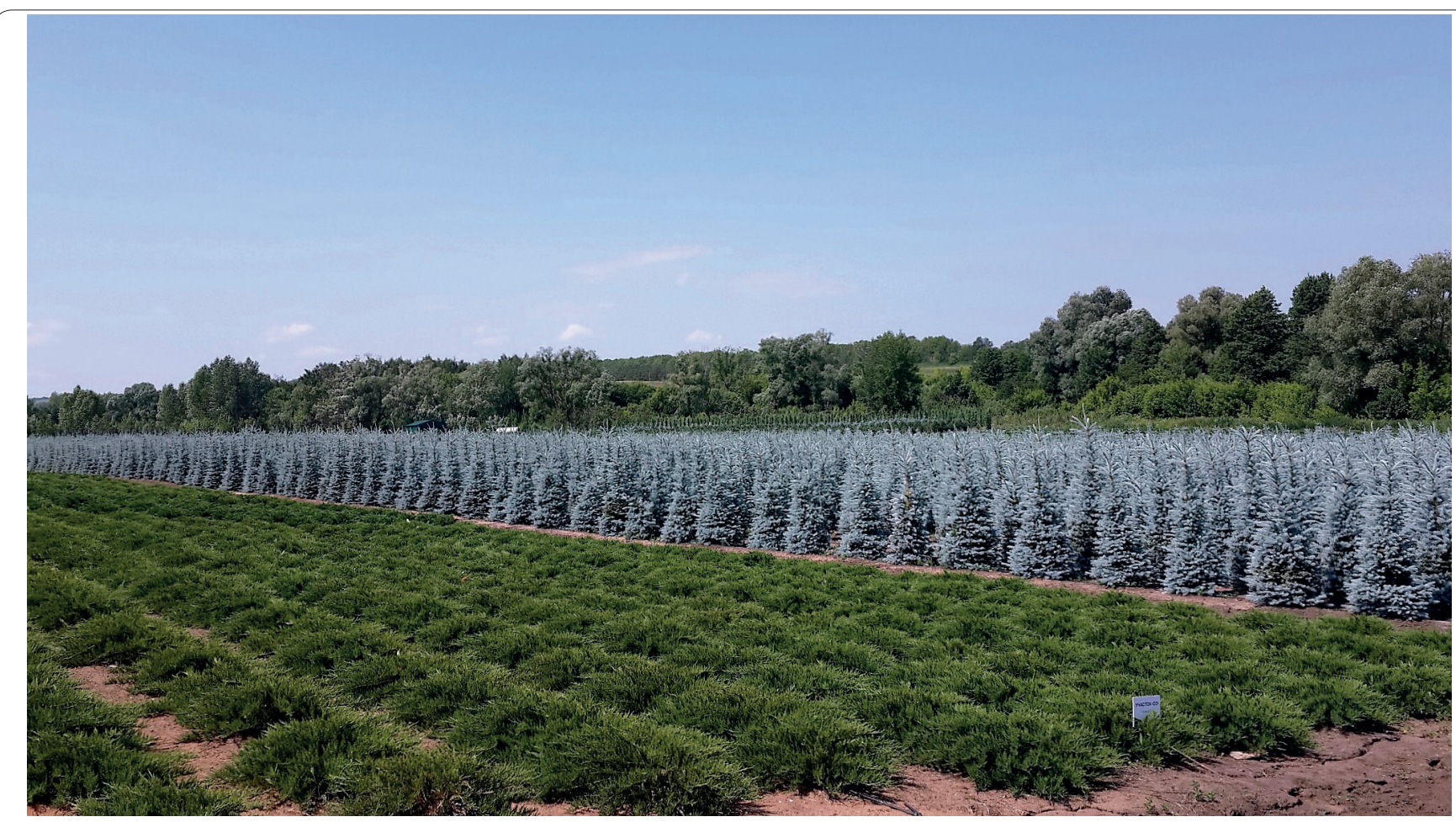

Можжевельники и голубые ели в питомнике «Императорский» (Татарстан).

Здесь выращивают широкий ассортимент хвойных растений

перспективных примеров. Амурский филиал Ботанического сада-института ДВО РАН (Благовещенск) активно занимается интродукцией редких дикорастущих растений, в том числе занесенных в Красную книгу РФ, изучает их поведение в культуре, дает рекомендации по их выращиванию в условиях местного климата. Ботанический сад-институт ДВО РАН занимается интродукцией и введением в культуру природных видов растений семейства толстянковые, произрастающих на Дальнем Востоке.
А вот дальше включается воображение: ботанические сады передают некоторое количество посадочного материала этих экзотов в питомники (на Дальнем Востоке их пока немного, но они есть и входят в АППМ), которые их размножают в соответствии с рекомендациями ученых. Дальнейшая судьба этих растений может быть различной: прежде всего, питомники станут реализовывать красивоцветущие и декоративнолиственные виды цветоводам-любителям, ландшафтным архитекторам и дизайнерам, озе-

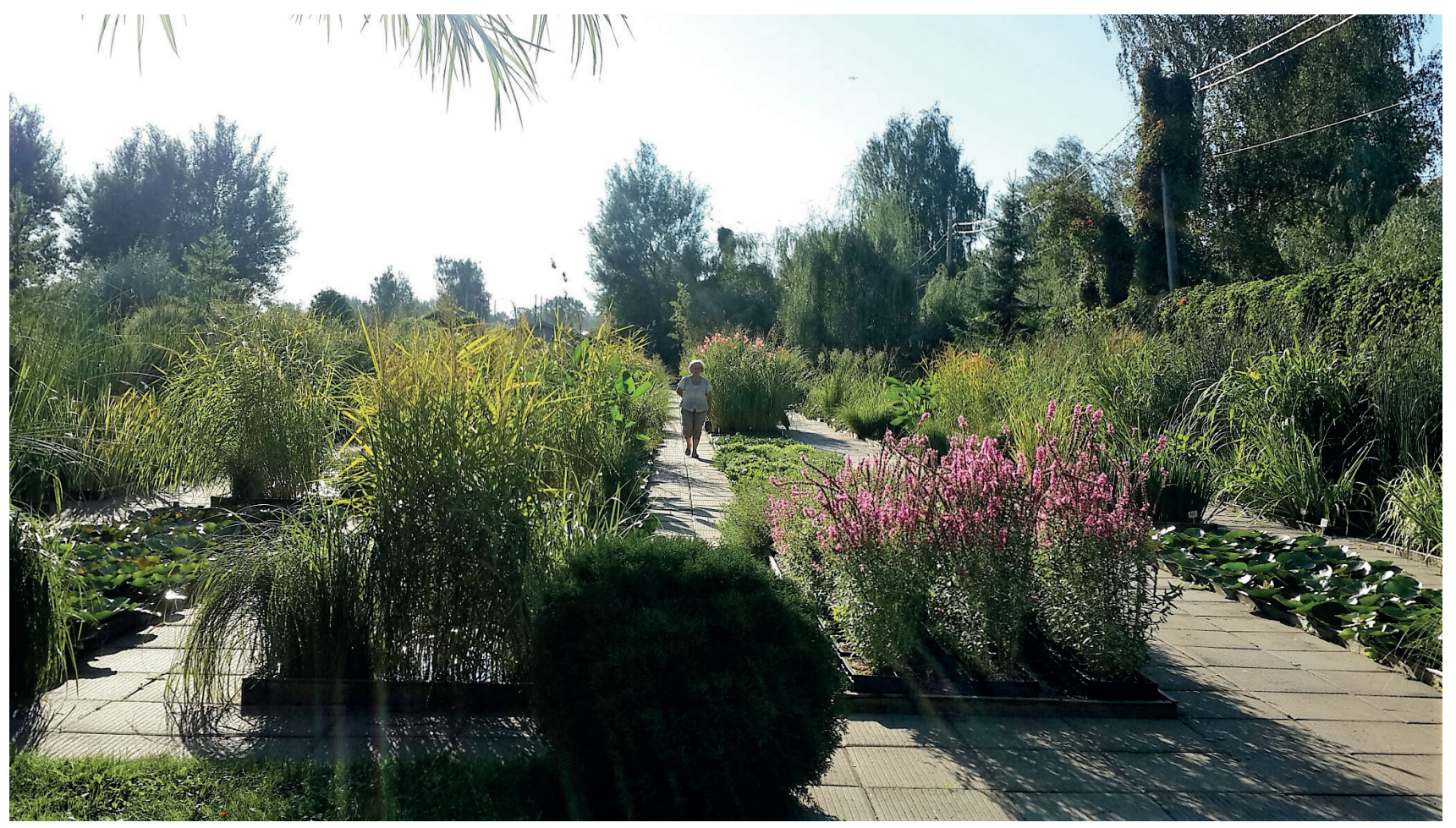

В питомнике водных растений А. Марченко 
ленителям. Кроме того, окультуренные растения могут стать предметом экспорта. Это совсем не шутка, по собственному опыту знаю, как живо зарубежные ученые и представители селекционных фирм интересуются растениями нашей природной флоры. Тут стоит вспомнить давнюю историю о видовых дикорастущих тюльпанах, вывезенных из СССР и давших начало многим знаменитым голландским сортам, созданным селекционерами Дереком и Карлом Лефебрами. Надо отдать им должное, они не скрывали, что своим успехом они обязаны «советским» тюльпанам, о чем свидетельствуют названия тех первых полученных ими сортов - 'Большой Театр', 'Академик Цицин', 'Памяти Ленина', 'Юрий Гагарин’ и др.

Из питомников эти растения могут вернуться к ученым-селекционерам в научные учреждения, или ученые-селекционеры придут в питомники, чтобы заняться их улучшением, созданием новых интересных сортов с более крупными красивыми цветками разных окрасок. Однако надо четко понимать, что такая работа займет длительное время, что она не принесет «быстрых» денег, а самое главное, кто-то должен стать пионером подобных исследований и взять на себя инициативу.

Подобное сотрудничество положит начало новому этапу развития декоративного садоводства в стране.
Совместные проекты ботанических садов и бурно развивающихся питомников (в числе которых уже есть несколько, работающих с новыми современными технологиями клонального микроразмножения растений) могут дать импульс возрождению селекции декоративных культур, введению в культуру новых высокодекоративных видов природной флоры, которыми так богата наша страна, развитию сотрудничества с зарубежными фирмами и питомниками, выходу отечественного цветоводства на мировой рынок (кажется, в своих мечтах я зашла слишком далеко, вспомнился Остап Бендер, рисующий сияющие перспективы развития шахматного движения в стране и скорое превращение Васюков в Нью-Москву). И все-таки выход на мировой рынок возможен, но только в случае появления свежих идей и решений, поскольку при всем желании наши цветоводы не вырастят розы лучше (и дешевле), чем в Эквадоре, Колумбии и Кении, не обойдут голландских селекционеров тюльпанов и французских селекционеров роз (на их стороне многовековой опыт и финансовые возможности) и т. д. Но свежие идеи и решения сегодня витают в воздухе, о чем свидетельствует бурное развитие питомниководства. Нужно только суметь не упустить момент и воспользоваться благоприятными обстоятельствами.

\section{Литература}

\section{Список русскоязычной литературы}

1. Арцибашев ДД. Декоративное садоводство. М.: Сельхозгиз; 1941.

2. Болотова ЯВ, Дарман ГФ, Воробьева АА, Крещенок ИА. Растения Красной книги России в коллекции Амурского филиала Ботанического сада-института ДВО РАН. Цветоводство. 2012;(5):17-21.

3. Борисов БА, Карпун НН, Журавлева ЕН, Борисова ИП. Оценка возможности биологического контроля самшитовой огневки энтомопаразитическими грибами. В кн.: Мониторинг и биологические методы контроля вредителей и патогенов древесных растений: от теории к практике. Материалы Всероссийской конференции с международным участием. М.; 2016. c. $41-4$.

4. Гончарова СН, Колдаева МН, Белуха АC. Дальневосточные толстянковые в культуре. Цветоводство. 2011;(5):20-4.

5. Ижевский СС. Биотический дождь, или Спасайся, кто может. 2015;(2):28-9.

6. Кабанов АВ. Что же сажать в городе? Цветоводство. 2015;(1):35-7.

7. Калгин ВН. Фиалочный танец в Техасе. Узамбарская фиалка. Цветоводство. 2013;(6):2-7.

8. Келина АВ. Цветоводство Юга России. История, современность, перспективы. Цветоводство. 2014;(1):19-20.

9. Крюкова ИВ. Никитский ботанический сад. История и судьбы. Симферополь: Н. Оріанда; 2011.

10. Новицкая ГВ. Деревья в городе. Цветоводство. 2009;(5):34-7.
11. Рындин АВ, Карпун НН, Келина АВ. Особенности и перспективы развития субтропического декоративного садоводства России. Цветоводство. 2013;(5):11-3.

12. Шатко ВГ. Сад прекрасный и старинный (к 200-летию Никитского ботанического сада). Цветоводство. 2013;(2):16-9.

13. Шашкова ЛС. Внимание: время пошло! Цветоводство. 2014;(2):6-7.

14. Шашкова ЛС. Отечественные цветы: мечта или реальность? Цветоводство. 2014;(3):4-5.

15. Шашкова ЛС. Крымские встречи: актуальный репортаж. Цветоводство. 2014;(5):3-6.

16. Шашкова ЛС, Андриевская НА. «Галантус», Калуга: весна приходит зимой. Цветоводство. 2013;(3):4.

17. Шашкова ЛС, Хитрова ЛМ. Москва-Сочи: наука между прошлым и будущим. Цветоводство. 2013;(6):2-5.

\section{Общий список литературы/Reference List}

1. Artsybashev DD. Dekorativnoye Tsvetovodstvo [Horticulture]. Moscow: Selkhozgiz; 1941. (In Russ.)

2. Bolotova YaV, Darman GF, Vorobjeva AA, Kreschenok IA. [Far East plants from "The Red Books of Russia" in the Far East Botanical GardenInstitute]. Tsvetovodstvo. 2012;(5):17-21. (In Russ.) 3. Borisov BA, Karpun NN, Zhuravleva EN, Borisova IP. [Possibilities for biological control of box tree moth with entomoparasitic fungi]. In: Monitoring i Biologicheskiye Medody Kontrolia Vrediteley i Patogenov Drevesnykh Rasteniy: On Teorii k Praktike. Materialy Vserossiyskoy 
Konferentsii s Mezhdunarodnym Uchastiyem. [Monitoring and Methods of the Biological Control of Woody Plant Pests and Pathogens: From Theory to Practice. Proceedings of All-Russian Conference with International Involvement]. Moscow: 2016. P. 41-4. (In Russ.)

4. Goncharova SN, Koldayeva MN, Belukha AS. [Far East Crossulaceae in culture]. Tsvetovodstvo. 2011;(5):20-4. (In Russ.)

5. Izhevsky SS. [Alarm: quarantine pests and diseases]. Tsvetovodstvo. 2015;(2):28-9. (In Russ.)

6. Kabanov AV. [Promising plants for urban landscapes]. Tsvetovodstvo. 2015;(1):35-7. (In Russ.)

7. Kalgin VN. [Violets dance across Texas]. Usambarskaja fialka 2013;(6):2-7. (In Russ.)

8. Kelina AV. [Russian subtropical floriculture: past, present and future]. Tsvetovodstvo. 2014;(1):19-20. (In Russ.)

9. Krjukova IV. Nikitskiy Botanicheskiy Sad: Istoriya i Sud'by. [Nikitskiy Botanical Gardens. History and Destinies]. Simferopol: N. Oreanda, 2011. (In Russ.)
10. Novitskaya GV. [Trees in the city]. Tsvetovodstvo. 2009;(5):34-7. (In Russ.)

11. Ryndin AV, Karpun NN, Kelina AV. [Peculiarities and the prospects of development of subtropical horticulture in Russia]. Tsvetovodstvo. 2013;(5):11-3. (In Russ.)

12. Shatko VG. [Garden beautiful and age-old. On the $200^{\text {th }}$ Anniversary of Nikitskiy Botanical Garden]. Tsvetovodstvo. 2013;(2):16-9. (In Russ.)

13. Shashkova LS. [To grow flowers in Russia is now profitable]. Tsvetovodstvo. 2014;(2):6-7. (In Russ.)

14. Shashkova LS. [Russian floriculture: good prospects of small and medium-size businesses]. Tsvetovodstvo. 2014;(3):4-5. (In Russ.)

15. Shashkova LS. [Meetings with Crimean flower growers: Topical reportage]. Tsvetovodstvo. 2014;(5):3-6. (In Russ.)

16. Shashkova LS, Andriyevskaya NA. [«Galanthus», Kaluga: Spring comes in winter]. Tsvetovodstvo. 2013;(3):4. (In Russ.)

17. Shashkova LS, Khitrova LM. [MoscowSochi: Floriculture science between past and future]. Tsvetovodstvo. 2013;(6):2-5.

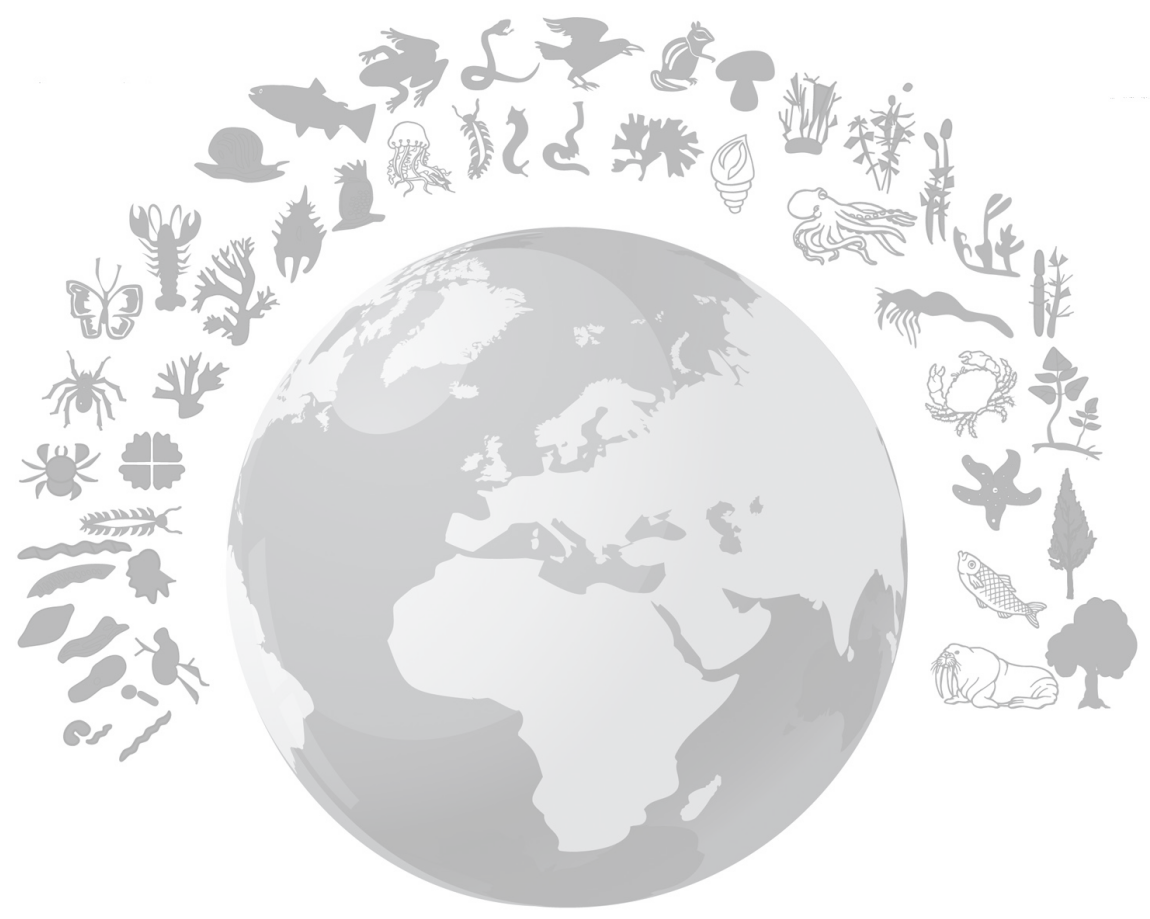

